\title{
Cell cycle regulation by bevacizumab in ARPE-19 human retinal pigment epithelial cells
}

\author{
CHIEN-NENG KUO ${ }^{1,2}$, CHUNG-YI CHEN $^{3}$, CHIEN-HSIUNG LAI ${ }^{1,2}$, LI-JU LAI ${ }^{1,2}$, \\ PEI-CHEN WU ${ }^{1,2}$, CHIA-HUI HUNG ${ }^{2,4}$ and CHING-HSEIN CHEN ${ }^{5}$ \\ ${ }^{1}$ Department of Ophthalmology, Chang Gung Memorial Hospital, Chiayi; \\ ${ }^{2}$ Chang Gung University College of Medicine and Chang Gung University of Science and Technology; \\ ${ }^{3}$ Department of Medical Laboratory Science and Biotechnology, School of Medicine and Health Sciences, Fooyin University, \\ Kaohsiung 83102; ${ }^{4}$ Department of Dermatology, Chang Gung Memorial Hospital, Chiayi; ${ }^{5}$ Department of Microbiology, \\ Immunology and Biopharmaceuticals, College of Life Sciences, National Chiayi University, Chiayi, Taiwan 60004, R.O.C.
}

Received March 26, 2012; Accepted June 29, 2012

DOI: $10.3892 / \mathrm{mmr} .2012 .986$

\begin{abstract}
Bevacizumab, a recombinant humanized monoclonal antibody, binds vascular endothelial growth factor (VEGF) and inhibits its interaction with receptors found on endothelial cells. Bevacizumab has been increasingly used as an off-label treatment for exudative age-related macular degeneration (AMD). Whether or not bevacizumab is capable of arresting the growth of human retinal pigment epithelial cells remains to be clarified. In this study, flow cytometry was used to evaluate whether bevacizumab markedly induced the $G_{1} / S$ phase arrest. The $G_{1} / S$ phase cycle-related protein analysis demonstrated that the expression of cyclin-dependent kinase (CDK)2, 4 and 6 and of cyclin D and E, as well as the phosphorylation of retinoblastoma tumor suppressor protein (ppRB) production were found to be markedly reduced by bevacizumab. By contrast, the protein levels of p53, p16, p21 and p27 were increased in bevacizumab-treated ARPE-19 cells (a human retinal pigment epithelial cell line). These events of $\mathrm{G}_{1} / \mathrm{S}$ arrest induced by bevacizumab in ARPE-19 cells suggest that a preventive effect of bevacizumab exists in AMD.
\end{abstract}

\section{Introduction}

Bevacizumab (Avastin ${ }^{\circledR}$; Genentech, San Francisco, CA, USA), a recombinant humanized monoclonal antibody, binds vascular endothelial growth factor (VEGF) and inhibits its interaction with receptors found on endothelial cells $(1,2)$.

Correspondence to: Dr Ching-Hsein Chen, Department of Microbiology, Immunology and Biopharmaceuticals, College of Life Sciences, National Chiayi University, 300 Syuefu Road, Chiayi, Taiwan 60004. R.O.C

E-mail: chench@mail.ncyu.edu.tw

Key words: bevacizumab, human retinal pigment epithelial cells, cell cycle, G1/S arrest, age-related macular degeneration
Bevacizumab has been increasingly used as an off-label treatment for exudative age-related macular degeneration (AMD) (2). Retinal angiomatous proliferation, a variant of exudative neovascular AMD, has been described to occur in 3 stages: i) intraretinal neovascularization, ii) subretinal neovascularization with (stage IIB) or without (stage IIA) serous pigment epithelial detachment (PED) and iii) a vascularized PED with retinal-choroidal anastomosis (RCA) (3). The ocular complications of bevacizumab intravitreal injection included corneal abrasion, chemosis, lens injury, ocular inflammation, retinal pigment epithelial tear and acute vision loss. The systemic complications included cerebral infarction, elevation of systolic blood pressure, facial skin redness, itchy diffuse rash and menstrual irregularities (4). Another study demonstrated that retinal pigment epithelial (RPE) tears occur after intravitreal bevacizumab injections for exudative AMD in approximately $1.6 \%$ of the eyes and may cause severe vision loss. Intravitreal bevacizumab injections also cause RPE tears in patients with predominantly classic choroidal neovascularization (5). The serial intravitreal injection of bevacizumab caused a large retinal pigment epithelium rip resulting in a large fibrovascular pigment epithelial detachment (6). It has been hypothesized that intravitreal bevacizumab induces contraction of choroidal neovascular membranes, thus accelerating RPE tear development (2).

An in vitro study demonstrated that bevacizumab at a concentration of $2.5 \mathrm{mg} / \mathrm{ml}$ caused a moderate decrease in ARPE-19 cell numbers and cell viability after 2 days of treatment (7). Bevacizumab caused a dose-dependent suppression of DNA synthesis in pig choroidal endothelial (CEC) cells, as a result of a moderate antiproliferative activity (maximum reduction $36.8 \%)$. At higher doses $(2.5 \mathrm{mg} / \mathrm{ml})$ bevacizumab may be harmful to the retinal pigment epithelium (7). However, after 2 days at a bevacizumab concentration of $2.5 \mathrm{mg} / \mathrm{ml}$, a moderate decrease in ARPE-19 cell numbers and cell viability was observed.

However, the mechanisms by which bevacizumab induced the cell cycle arrest in ARPE-19 cells has yet to be determined. The present study aimed to clarify the role of bevacizumab 
in the cell cycle and the effects of DNA synthesis on human ARPE-19 cells, as well as provide understanding of the molecular pathway of the function of bevacizumab in cell cycle regulation.

\section{Materials and methods}

Evaluation of the bevacizumab-induced cell cycle and DNA synthesis inhibition in human ARPE-19 cells. Cells were cultured in $60-\mathrm{mm}$ tissue-culture dishes $\left(8 \times 10^{5} \mathrm{cells} / \mathrm{dish}\right)$. The culture medium was replaced by a new medium after $24 \mathrm{~h}$ and subsequently exposed to $2.5 \mathrm{mg} / \mathrm{ml}$ bevacizumab for $48 \mathrm{~h}$. After treatment, adherent and floating cells were pooled, washed with PBS, fixed in PBS-methanol (1:2 volume/volume) solution, and maintained at $4^{\circ} \mathrm{C}$ for at least $18 \mathrm{~h}$. Following 2 more washes with PBS, the cell pellets were stained with the propidium iodide (PI) fluorescent probe solution containing PBS, $40 \mu \mathrm{g} /$ $\mathrm{ml} \mathrm{PI}$, and $40 \mu \mathrm{g} / \mathrm{ml}$ DNase-free RNase A for $30 \mathrm{~min}$ at room temperature in the dark. DNA fluorescence of PI-stained cells was evaluated by excitation at $488 \mathrm{~nm}$ and monitored through a 630/22-nm band pass filter using flow cytometry. A minimum of 10,000 cells was analyzed per sample, and the DNA histograms were gated and further analyzed using Modfit software on a Mac workstation to estimate the percentages of cells in various phases of the cell cycle.

Evaluation of the bevacizumab-induced expression of cell cycle-regulated proteins in human ARPE-19 cells. ARPE-19 cells $\left(1 \times 10^{6}\right)$ were cultured in $60-\mathrm{mm}$ tissue-culture dishes for $24 \mathrm{~h}$. The culture medium was replaced with a new medium and exposed to bevacizumab for the indicated time points. After treatment, the cells were washed with PBS, re-suspended in a protein extraction buffer for $10 \mathrm{~min}$ and then centrifuged at $12,000 \mathrm{x} \mathrm{g}$ for $10 \mathrm{~min}$ at $40^{\circ} \mathrm{C}$ to obtain total extracted proteins (supernatant). The protein concentrations were measured usinga Bio-Rad protein assay reagent (Bio-Rad, Richmond, CA, USA). The expression of cell cycleregulated proteins was evaluated by western blotting. Briefly, the total extracted proteins were boiled in loading buffer, and an aliquot corresponding to $50 \mu \mathrm{g}$ of protein was separated by $12 \%$ SDS-polyacrylamide gel. After electrophoresis, the proteins were electrotransferred onto a polyvinylidene fluoride transfer membrane. The membranes were then incubated with the primary antibody of various cell cycle-regulated proteins overnight, and washed with PBST solution $(0.05 \%$ Tween-20 in PBS). Following washing, the secondary antibody labeled with horseradish-peroxidase was adjacently incubated for $1 \mathrm{~h}$, and washed with PBST solution (0.05\% Tween-20 in PBS). The antigen-antibody complexes were detected by enhanced chemiluminescence (Amersham Pharmacia Biotech, Piscataway, NJ, USA) with a chemiluminescence analyzer.

Evaluation of the bevacizumab-induced cell viability in human ARPE-19 cells. ARPE-19 cells $\left(8 \times 10^{5}\right)$ were cultured in $60-\mathrm{mm}$ tissue-culture dishes for $24 \mathrm{~h}$. The culture medium was replaced with a new medium and then exposed to $0,2.5$ and $5.0 \mathrm{mg} / \mathrm{ml}$ of bevacizumab for $24 \mathrm{~h}$. After treatment, the ARPE-19 cells were incubated for $2 \mathrm{~h}$ with $0.5 \mathrm{mg} / \mathrm{ml}$ of MTT reagent and lysed with DMSO. The absorbance was measured at $570 \mathrm{~nm}$ in a microplate reader.

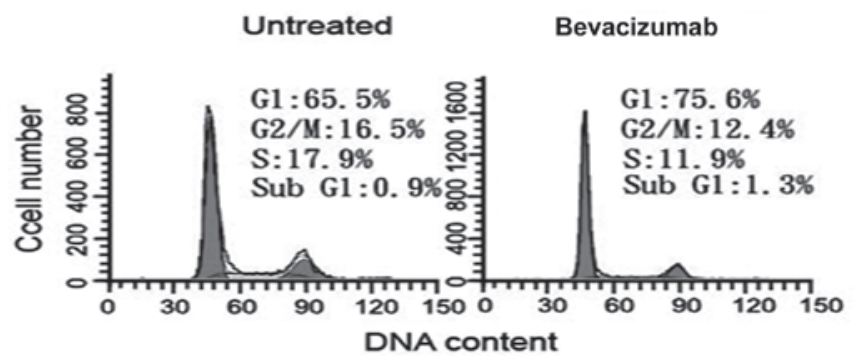

Figure 1. Cell cycle analysis in the the bevacizumab-treated ARPE-19 cell line. Cells were plated in 60-mm culture dishes at $80 \%$ confluence and then treated with 0 or $2.5 \mathrm{mg} / \mathrm{ml}$ bevacizumab for $48 \mathrm{~h}$. After treatment, adherent and floating cells were collected, fixed in PBS-methanol (1:2, volume/ volume) solution and stained with propidium iodide, followed by flow cytometric analysis. The data in each panel show the percentages of the cell cycle within the cells.

\section{Results}

Bevacizumab induced $G_{I} / S$ phase arrest in ARPE-19 cells. We initially used PI staining and flow cytometry to evaluate whether bevacizumab is capable of disrupting the cell cycle progression. The $G_{1}$ and $S$ phases were 65.5 and $17.9 \%$ in untreated cells, respectively (Fig. 1). Treatment with $2.5 \mathrm{mg} / \mathrm{ml}$ bevacizumab resulted in a marked decrease in the $\mathrm{S}$ phase (11.9\%) at $48 \mathrm{~h}$, suggesting that bevacizumab inhibits DNA synthesis in ARPE-19 cells. The $\mathrm{G}_{1}$ phase increased slightly to $75.6 \%$ following treatment with bevacizumab, indicating a $\mathrm{G}_{1} / \mathrm{S}$ arrest during bevacizumab treatment in ARPE-19 cells.

Effect of bevacizumab on cell cycle regulatory proteins in ARPE-19 cells. Based on the observation that bevacizumab induced a $\mathrm{G}_{1} / \mathrm{S}$ arrest in ARPE-19 cells, we evaluated the effect of bevacizumab on cell cycle regulatory proteins that are important in $\mathrm{G}_{1} / \mathrm{S}$ cell cycle progression, using western blot analysis. As shown in Fig. 2A, bevacizumab treatment induced a decrease in the protein level of cyclin $\mathrm{D}$ in ARPE-19 cells that were clearly visible after 6,12 and $48 \mathrm{~h}$ of treatment. The expression of cyclin E increased slightly after $6 \mathrm{~h}$ of treatment, followed by a marked upregulation after 12 and $24 \mathrm{~h}$, compared with the untreated cells. Thus, the bevacizumab-mediated $\mathrm{G}_{1} / \mathrm{S}$ phase cell cycle arrest of ARPE-19 cells correlated with the inhibition of cyclin D and $\mathrm{E}$. The bevacizumab-treated ARPE-19 cells also demonstrated a decrease in the protein levels of CDK2, 4 and 6 that was visible after 6,12 and $24 \mathrm{~h}$ of treatment (Fig. 2B). Consistent with cyclin D and CDK4 downregulation, bevacizumab markedly inhibited the phosphorylation of $\mathrm{pRb}(\mathrm{ppRb})$ at $24 \mathrm{~h}$ (Fig. 3). Moreover, to gain further insights into the mechanism of bevacizumab-mediated $\mathrm{G}_{1} / \mathrm{S}$ phase arrest, we determined its effect on p53, p21, p16 and p27 protein expressions by immunoblotting. Bevacizumab treatment resulted in a time-dependent increase in the protein expressions of $\mathrm{p} 53$, p21, p16 and p27 in ARPE-19 cells (Fig. 4).

Bevacizumab inhibited cell viability in ARPE-19 cells. Our study demonstrated that bevacizumab at a concentration of 2.5 $\mathrm{mg} / \mathrm{ml}$ in $24 \mathrm{~h}$ caused a moderate decrease of the $\mathrm{G}_{1} / \mathrm{S}$ phase in ARPE-19 cells (Fig. 1). The MTT assay was subsequently used 


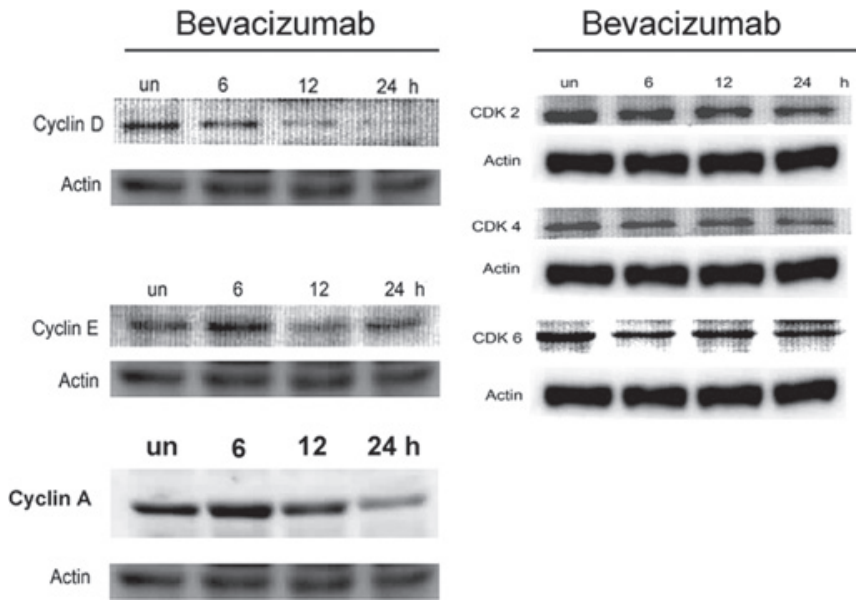

Figure 2. The effect of bevacizumab on the expression of (A) cyclin D and $\mathrm{E}$ and (B) CDK2, 4 and 6. ARPE-19 cells were treated with $5 \mathrm{mg} / \mathrm{ml}$ of bevacizumab for 6,12 and $24 \mathrm{~h}$. After treatment, the cells were washed with PBS and extracted with protein extraction buffer. Fifty micrograms of the proteins were loaded on a $12 \%$ SDS-polyacrylamide gel. The expression of various proteins and actin (as a loading control) was evaluated by western blotting as outlined in Materials and methods. These experiments were performed at least 3 times and a representative experiment is presented.

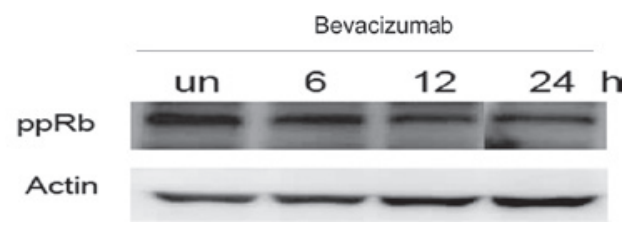

Figure 3. The effect of bevacizumab on the expression of ppRb. ARPE-19 cells were treated with $5 \mathrm{mg} / \mathrm{ml}$ of bevacizumab for 6,12 and $24 \mathrm{~h}$. After treatment, the cells were washed with PBS and extracted with protein extraction buffer. Fifty micrograms of the proteins were loaded on a $12 \%$ SDS-polyacrylamide gel. The expression of various proteins and actin (as a loading control) was evaluated by western blotting as described in Materials and methods. These experiments were performed at least 3 times and a representative experiment is presented.

to prove that bevacizumab $(5.0 \mathrm{mg} / \mathrm{ml})$ treatment inhibited the cell viability to $80 \%$ in ARPE-19 cells after $48 \mathrm{~h}$ (Fig. 5).

\section{Discussion}

Bevacizumab inhibited monkey choroidal endothelial cells at $2.0 \mathrm{mg} / \mathrm{ml}$ on cell viability, however, no effect was noted on the ARPE-19 and RGC-5 cell lines at $2.0 \mathrm{mg} / \mathrm{ml}$ (8). Results of that study are similar to our findings demonstrating that bevacizumab treatment did not reduce the cell viability at $2.5 \mathrm{mg} / \mathrm{ml}$ in ARPE-19 cells at $24 \mathrm{~h}$. In the higher concentration of bevacizumab $(5 \mathrm{mg} / \mathrm{ml})$, cell viability was reduced to $80 \%$ suggesting that bevacizumab might affect the cell cycle of ARPE-19 cells. A recent study reported that bevacizumab has a cytostatic effect of VEGF inhibition on multiple myeloma. This malignancy of plasma cells was determined through the attenuation of critical signaling effectors: VEGF receptor 1, mTOR, c-Myc, Akt, STAT3 and eIF4E (9). In addition, bevacizumab has a direct effect on major pathways critically activated in multiple myeloma that is independent from its established effect on angiogenesis (9). These effects of bevacizumab were

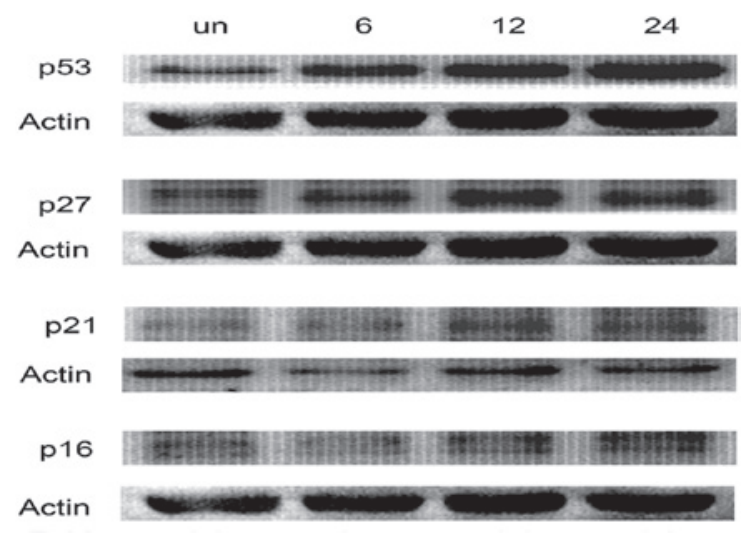

Figure 4. The effect of bevacizumab on the expression of p53, p27, p21 and p16. ARPE-19 cells were treated with $5 \mathrm{mg} / \mathrm{ml}$ of bevacizumab for 6,12 and $24 \mathrm{~h}$. After treatment, the cells were washed with PBS and extracted with protein extraction buffer. Fifty micrograms of the proteins were loaded on a $12 \%$ SDS-polyacrylamide gel. The expression of various proteins and actin (as a loading control) was evaluated by western blotting as outlined in Materials and methods. These experiments were performed at least 3 times and a representative experiment is presented.

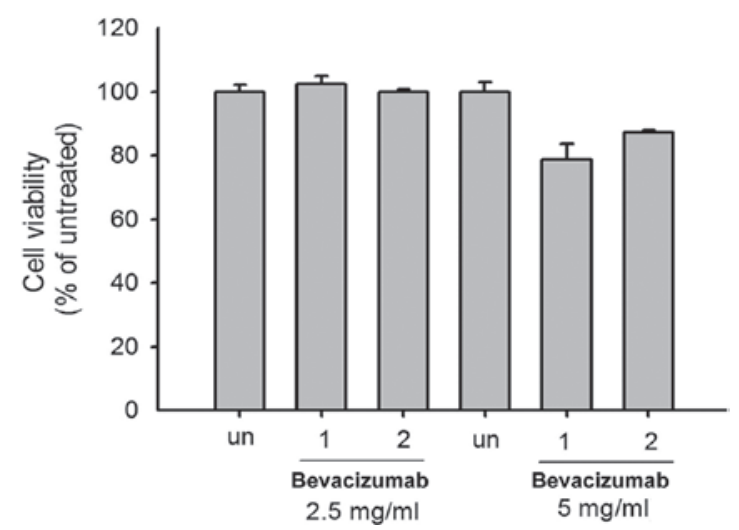

Figure 5. Cell viability analysis in bevacizumab (avastin)-treated ARPE-19 cells. Cells were plated in $60-\mathrm{mm}$ culture dishes at $80 \%$ confluence and then treated with 0 (un), 2.5 or $5 \mathrm{mg} / \mathrm{ml}$ of bevacizumab for $24 \mathrm{~h}$. The MTT reagent $(0.5 \mathrm{mg} / \mathrm{ml})$ was added to the cells for $2 \mathrm{~h}$ at $37^{\circ} \mathrm{C}$ and then lysed with DMSO. The absorbance was measured at $575 \mathrm{~nm}$.

achieved using high concentrations $(2 \mathrm{mg} / \mathrm{ml})$. These results indicate that bevacizumab had a higher cytostatic effect on multiple myeloma, compared with the ARPE-19 and RGC-5 cell lines at $2 \mathrm{mg} / \mathrm{ml}$.

CDK2, 4 and 6, as well as cyclins D and E, are various driving forces for the $\mathrm{G}_{1} / \mathrm{S}$ phase of the cell cycle (10). Therefore, significant decreases in the protein expression of cyclin $\mathrm{D}, \mathrm{E}$ and $\mathrm{A}$, as well as CDK2, 4 and 6 due to bevacizumab suggest a potential inhibition on ARPE-19 cell growth through cell cycle regulation (Fig. 2A and B). The upregulation of p53 at 0 and $48 \mathrm{~h}$ alone, with a marked induction of the expression of p16, p21 and p27 at $48 \mathrm{~h}$ was also observed (Fig. 2D). Moreover, the accumulation of p53 induces the upregulation of cell cycle-regulatory proteins, such as p21 and p27, whereas the induction of these genes leads to $\mathrm{G}_{0} / \mathrm{G}_{1}$ arrest (11).

Cyclins, such as type $D$ and $E$ regulate $G_{1} / S$ phase cell cycle progression through the activation of specific CDK that phosphorylates the $\mathrm{pRb}$ protein, thereby decreasing the repression 
of E2F-DP transactivation of S-phase genes (12). Loss of cyclin $D$ causes $G_{1}$ arrest in some cells, but in other cell lines, the downstream cyclin $E$ protein replaces cyclin $D$ and aids $G_{1} / S$ progression (13). In bevacizumab treatment, the expression of cyclin $\mathrm{E}$ increased slightly at $24 \mathrm{~h}$ in ARPE-19 cells (Fig. 2A). However, the downregulation of cyclin D1 started at $6 \mathrm{~h}$ and sustained to $24 \mathrm{~h}$ in bevacizumab treatment (Fig. 2A). This seems to explain the downregulation of cyclin D1, but not of cyclin $\mathrm{E}$, and is a main factor for bevacizumab-induced $\mathrm{G}_{1} / \mathrm{S}$ arrest. Findings of another study also demonstrated that cyclin D1 degradation is sufficient to induce $\mathrm{G}_{1}$ cell cycle arrest despite the constitutive expression of cyclin E2 in ovarian cancer cells (12). CDKs are regulated by distinct protein sequences, including the cyclins required for the CDK activity and inhibitor (CKI) proteins (14). Results of the western blotting demonstrated that bevacizumab decreased cyclin D1 levels (Fig. 2A). The protein levels of CDK2, 4 and 6 were also inhibited by bevacizumab at $24 \mathrm{~h}$ (Fig. 2B). In addition, CKIs, such as p16, p21 and p27 were increased by bevacizumab, at least within a 6- to 24-h treatment period (Fig. 2D). Therefore, the inhibitory effect of bevacizumab on cell cycle-regulated proteins, not only inhibited the expression of cyclins/CDKs, but also promoted the expression of CKIs.

Factors associated with the $\mathrm{Rb}$ family proteins are recognized as determining downstream targets of $\mathrm{G}_{1}$-specific cyclin/CDK complexes (15). In hypophosphorylation, the $\mathrm{Rb}$ proteins correlate with and suppress the activity of E2F family transcription factors, which are involved in the transcription of key cell cycle-regulatory proteins (16). Upon growth stimulation, the $\mathrm{G}_{1}$-specific cyclins/CDKs phosphorylate $\mathrm{Rb}$, resulting in the release of $\mathrm{E} 2 \mathrm{~F}$ factors and progression into the $\mathrm{S}$ phase (16). The phosphorylation of $\mathrm{Rb}$ provides a crucial role in the progression of the $\mathrm{G}_{1}$ phase and the transition of $\mathrm{G}_{1}$ to $\mathrm{S}$ phase (17). Ser795 in $\mathrm{pRb}$ is a specific site for phosphorylation by the cyclin D/CDK4 complex in the $\mathrm{G}_{0} /$ $\mathrm{G}_{1}$ phase (18). The treatment with bevacizumab resulted in the inhibition of cyclin D and CDK4 expression in ARPE-19 cells, as well as the prevention of CDK4 from phosphorylating $\mathrm{pRb}$ at Ser795, thereby arresting cell growth (Fig. 2). Another study demonstrated that the $\mathrm{p} 21$ protein binds to cyclin/CDK complexes resulting in inhibition of the $\mathrm{G}_{1} / \mathrm{S}$ phase transition by inhibiting the phosphorylation of the $\mathrm{Rb}$ protein (19). The decrease in phosphorylated $\mathrm{Rb}$ proteins, therefore, might result from bevacizumab-triggered $\mathrm{p} 21$ expression and the decreased expression of cyclin-CDK. Generally, we observed that bevacizumab inhibited cell growth in ARPE-19 cells. We, therefore, suggest a novel pathway by which bevacizumab regulates cell cycle progression in ARPE-19 cells. Bevacizumab was able to induce $\mathrm{p} 53$ production, and then upregulate the expression of p16, p21 and p27. These events decrease the expression of cyclin D and E, and CDK2, 4 and CDK 6, followed by the reduction of ppRb as well as the triggering of the $G_{1} / S$ arrest of the cell cycle.

\section{Acknowledgements}

This study was supported by a grant from the Chang Gung Memorial Hospital, ROC: CMRPG6B0041.

\section{References}

1. Luthra S, Narayanan R, Marques LE, Chwa M, Kim DW, Dong J, Seigel GM, Neekhra A, Gramajo AL, Brown DJ, et al: Evaluation of in vitro effects of bevacizumab (Avastin) on retinal pigment epithelial, neurosensory retinal, and microvascular endothelial cells. Retina 26: 512-518, 2006

2. Garg S, Brod R, Kim D, Lane RG, Maguire J and Fischer D: Retinal pigment epithelial tears after intravitreal bevacizumab injection for exudative age-related macular degeneration. Clin Experiment Ophthalmol 36: 252-256, 2008.

3. Forooghian F, Cukras C and Chew EY: Retinal angiomatous proliferation complicated by pigment epithelial tear following intravitreal bevacizumab treatment. Can J Ophthalmol 43: 246-248, 2008.

4. Shima C, Sakaguchi H, Gomi F, Kamei M, Ikuno Y, Oshima Y, Sawa M, Tsujikawa M, Kusaka S and Tano Y: Complications in patients after intravitreal injection of bevacizumab. Acta Ophthalmol 86: 372-376, 2008.

5. Arias L, Caminal JM, Rubio M, Pujol O and Arruga J: Retinal pigment epithelial tears after intravitreal bevacizumab injection for predominantly classic choroidal neovascularization. Eur J Ophthalmol 17: 992-995, 2007.

6. Subramanyam A, Phatak S and Chudgar D: Large retinal pigment epithelium rip following serial intravitreal injection of avastin in a large fibrovascular pigment epithelial detachment. Indian J Ophthalmol 55: 483-486, 2007.

7. Spitzer MS, Wallenfels-Thilo B, Sierra A, Yoeruek E, Peters S, Henke-Fahle S, Bartz-Schmidt KU, Szurman P; Tuebingen Bevacizumab Study Group: Antiproliferative and cytotoxic properties of bevacizumab on different ocular cells. Br J Ophthalmol 90: 1316-1321, 2006

8. Brar VS, Sharma RK, Murthy RK and Chalam KV: Evaluation of differential toxicity of varying doses of bevacizumab on retinal ganglion cells, retinal pigment epithelial cells, and vascular endothelial growth factor-enriched choroidal endothelial cells. J Ocul Pharmacol Ther 25: 507-511, 2009.

9. Attar-Schneider O, Drucker L, Zismanov V, TartakoverMatalon S, Rashid G and Lishner M: Bevacizumab attenuates major signaling cascades and eIF4E translation initiation factor in multiple myeloma cells. Lab Invest 92: 178-190, 2012.

10. Mueller A, Odze R, Jenkins TD, Shahsesfaei A, Nakagawa $\mathrm{H}$, Inomoto $\mathrm{T}$ and Rustgi AK: A transgenic mouse model with cyclin D1 overexpression results in cell cycle, epidermal growth factor receptor, and p53 abnormalities. Cancer Res 57: 5542-5549, 1997.

11. Yoo YA, Kim MJ, Park JK, Young Min Chung, Jong HL, Sung-Gil C, Jun SK, and Young DY: Mitochondrial ribosomal protein L41 suppresses cell growth in association with p53 and p27 ${ }^{\text {Kip1 }}$. Mol Cell Biol 25: 6603-6616, 2005.

12. Masamha CP and Benbrook DM: Cyclin D1 degradation is sufficient to induce G1 cell cycle arrest despite constitutive expression of cyclin E2 in ovarian cancer cells. Cancer Res 69: 6565-6572, 2009.

13. Yu Q, Geng Y and Sicinski P: Specific protection against breast cancers by cyclin D1 ablation. Nature 411: 1017-1021, 2001.

14. Sherr CJ and Roberts JM: Inhibitors of mammalian G1 cyclindependent kinases. Genes Dev 9: 1149-1163, 1995.

15. Sherr CJ: The Pezcoller lecture: cancer cell cycles revisited. Cancer Res 60: 3689-3695, 2000.

16. Vivar OI, Lin C, Firestone GL and Bjeldanes LF: 3,3'-Diindolylmethane induces a G1 arrest in human prostate cancer cells irrespective of androgen receptor and p53 status. Biochem Pharmacol 78: 469-476, 2009.

17. Jinno S, Hung SC and Okayama H: Cell cycle start from quiescence controlled by tyrosine phosphorylation of Cdk4 . Oncogene 18: 565-571, 1999.

18. Das SK, Hashimoto T and Kanazawa K: Growth inhibition of human hepatic carcinoma HepG2 cells by fucoxanthin is associated with down-regulation of cyclin D. Biochim Biophys Acta 1780: 743-749, 2008.

19. Ukomadu C and Dutta A: p21-dependent inhibition of colon cancer cell growth by mevastatin is independent of inhibition of G1 cyclin-dependent kinases. J Biol Chem 278: 43586-43594, 2003. 